INDIVIDUAL, SOCIAL, AND SEASONAL BEHAVIOR

OF THE THIRTEEN-LINED GROUND SQUIRREL

(SPERMOPHILES TRIDECEMLINEATUS)

APPROVED:

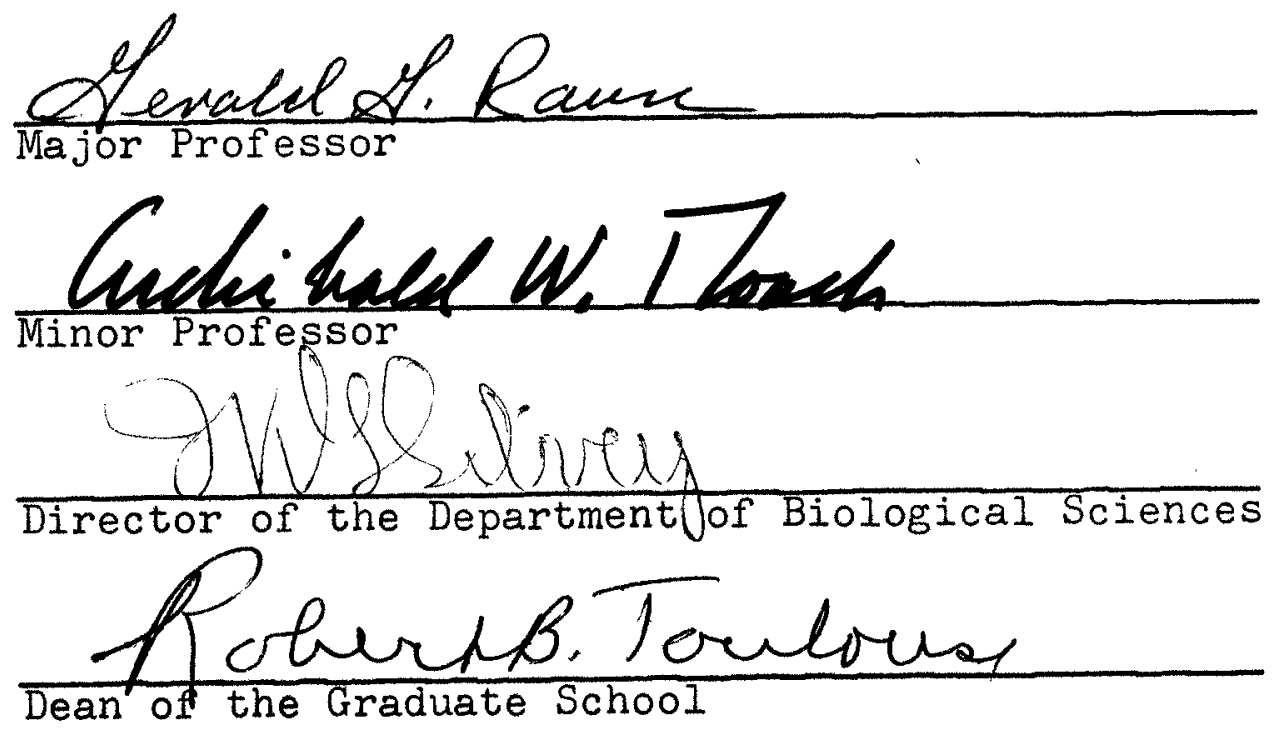




\section{INDIVIDUAL, SOCIAL, AND SEASONAL BEHAVIOR \\ OF THE THIRTEEN-LINED GROUND SQUIRREL \\ (SPERMOPHILUS TRIDECEMLINEATUS)}

\section{THESIS}

Presented to the Graduate Council of the North Texas State University in Partial Fulfillment of the Requirements

For the Degree of

MASTER OF ARTS

By

Harry E. Wistrand, B. A.

Denton, Texas

January, 1970 
TABLE OF CONTENTS

Page

IIST OF ILLUSTRATIONS . • . • • . . • . • • • . iv

Chapter

I. INTRODUCTION . . . . . . . . . . . I 1

Background

Statement of Purpose

II. METHODS AND MATERIALS . • . . . . . . 3

Description of Study Areas

Methods of Study

Study Dates and Times of Observations

III. OBSERTATIONS AND RESULTS . . . . . . . . 9

Individual Behavior

Social Behavior

IV. DISCUSSION . . . . . . . . . . . 54

LITERATURE CITED . . . . . . . . . . . 59 


\section{LIST OF ILLUSTRATIONS}

Figure

Page

1. Investigative Aiert Posture Assumed While Walking, Head Upraised . . . . . . . 12

2. Investigative Alert Postures Assumed While Squirrel is Sitting . . . . . . . . . . 13

3. Investigative Alert Postures Assumed by a Squirrel When Standing . . . . . . . . 14

4. Feeding Postures... . . . . . . . . 16

5. Stretching Position . . . . . . . . 20

6. Walking Positions . . . . . . . . . 29

7. Examples of Tail-Flicking . . . . . . . 31

8. Agonistic Threat Fosture with Tail Bristled . • 35

9. Female Receptive Posture During Courtship Just Prior to Mounting by a Male.... . . . 45 


\section{CHAPTER I}

\section{INTRODUC'TION}

Background

The thirteen-lined ground squirrel (Spermophilus tridecemlineatus) has been extensively studied with reference to hibernation (Johnson, 1929; Wade, 1950; Lyman, 1959; Kayser, 1965) and reproductive activities (Wade, 1927; Zimny, 1965; Bridgewater, 1966). The annual cycle and population dynamics of the species have been studied by Rongstad (1965) and McCarley (1966). Grubitz (1963), McCarley (1966), and Bridgewater (1966) investigated the behavior of these squirrels, but only McCarley observed them under natural conditions. Ethological studies have been made on other species of Spermophilus by Gordon (1943), Shaw (1945), Edwards (1946), Linsdale (1946), Balph and Stokes (1963), and Balph and Balph (1966).

Scott (1958) stated that in a study of animal behavior, "The best observational studies are done under natural or semi-natural conditions. . ." Grubitz (1963) maintained his experimental population in an enclosure, under what might be described as "semi-natural conditions," but artificially 
manipulated the population to produce unnatural situations. Food was placed in central feeding stations rather than being scattered randomly, and burrows were not always available to the squirrels. McCarley (1966) described escape, orientation, courtship, maternal, and juvenile behavior, but did not report on other behavior patterns.

\section{Statement of Purpose}

The purpose of this study is to provide a qualitative, detailed description of individual and social behavior in a free-living population of thirteen-lined ground squirrels. Behavioral differences in relation to various periods of the annual cycle are also evaluated. 
CHAPTER II

METHODS AND MATERIALS

Description of Study Areas

This study was conducted primarily at the Fairview Cemetery, Gainesville, Texas. McCarley (1966) suggests this may be the type locality of $\underline{\text { S. tridecemlineatus texensis }}$ (Howell, 1938). The cemetery is located in an area of blackland prairie in Cooke County, north-central Texas. The cemetery is bounded on the east by an old field, on the south by a 32-acre park, and on the north and west by housing units. The cemetery covers 54 acres, of which squirrels utilize about 45 acres. A population of about 50 adult and 80 juvenile ground squirrels was present during the study.

The soil in the cemetery is basically a sandy red clay. Sand was often placed on the gravesites, in which some squirrels showed a preference for burrow construction.

The most abundant vegetation present in the cemetery is Bermuda grass (Cynodon dactylon) and dallis grass (Paspalum dilatatum). Other abundant plants were crabgrass (Digitaria sanguinalis), three-awn (Aristida sp.), dandelion (Taraxacum officinale), hackberry (Celtus laevigata), arbor vitae (Thuja 
orientalis), Arizona cypress (Cypressus arizonica), Virginia juniper (Juniperus virginiana), mimosa (Mimosa strigullosa), and pyracantha (Pyracantha coccinea). Trumpet vine (Campsis radicans), cottonwood (Populus deltoides), Anerican elm (Ulmus americana), pecan (Carya illinoiensis), red oak (Quercus rubra), bur oak (Q. . macrocarpa), and blackjack oak (Q. marilandica) were a.lso present on the primary study area. The cemetery was often mowed ard watered, influencing the dominant vegetation types, and numerous species have been artificially introduced.

Many other vertebrates occur in association with the thirteen-lined ground squirrel in the cemetery. Herpetofauna found were the Rocky Mountain toad (Bufo woodhousei), Texas spiny lizard (Sceloporus olivaceus), and blue racer (Coluber constrictor). Birds observed include killdeer (Charadrius vociferus), mourning dove (Zenaidura macroura), purple martin (Progne subis), yellow-shafted flicker (Colaptes auratus), blue jay (Cyanocitta cristata), mockingbird (Mimus polyglottis), robin (Turdus migratorius), starling (Sternus vulgaris), boat-tailed grackle (Cassidix mexicarus), cardinal (Richmondena cardinalis), and house sparrow (Passer domesticus). Mammals seen were the eastern fox squirrel (Sciurus niger), blacktail jackrabbit (Lepus californicus), and eastern cottontail 
(Sylvilagus floridanus). Mice of the genera Mus and Peromyscus probably occur, but were not seen. Remains of armadillo (Dasypus novemcinctus) and opossum (Didelphis marsupialis) were found in the vicinity of the cemetery. Domestic cats and dogs were also seen.

Two additional localities were utilized. Some squirrels on the North Texas State University Golf Course, Denton, Texas, 30 miles south of Gainesville, were observed in the spring and early summer. Four squirrels from the golf course were introduced and observed on the campus of the University of Oklahoma Biological Station, Willis, Oklahoma, 30 miles northeast of Gainesville.

Al. localities are in the southern part of the range of the thirteen-lined grourid squirrel, as stated by McCarley (1966), who also pointed out that the optimum ecological requirements are apparently provided on golf courses and cemeteries.

\section{Methods of Study}

The thirteer-ined ground squirrel is an animal that is particularly suited for an ethological study under natural conditions. It is captured easily and selectively. It is easy to mark, and thus distinguish, individuals. It is not easily frightened or i.ts activity impeded by the presence 
of an observer. The population densities are generally high, and it is diurnal. The burdaries of the cemetery seemed to serve as a moderate barrier to dispersal.

Squirrels were captured by a noose, first described by McCarley (1966). The apparatus consists of a three-foot wooden dowel, with a two-and-one-half foot length of nylon cord attached. A noose was made from fifteen-pound nylon monofilament fishing line, tied to the rylon cord. If it was necessary to catch a particular squirrel, the squirrel was run into its burrow and the noose was placed around the inner edge of the burrow entrance. When the squirrel returned to the entrance and looked out of the burrow, the noose was pulled, snaring the squirrel. An adult squirrel could usually be captured in under ten minutes; less time was required for capture of a juvenile.

When initially captured, squirrels were marked permanently by toe-clipping. For sight identification, they were marked with Nyanzol A (red) and Nyanzol 2R (blue) fur dye. The dye was applied in stripes around the body. The combination of body area, width of stripe, and color provided a numerical sequence. The dye usually lasted for four to five weeks before it was necessary to re-dye a squirrel. Adults were marked according to the permanent number; juveniles were 
marked according to their litter number. A total of thirtyeight adults and sixteen juveniles was marked.

Although the population was dispersed over most of the cemetery, the density was highest in the southeastern quarter, and most observations were made there. The abundance of tombstones and large plants provided a method for noting the location of a squirrel.

There was a network of gravel and dirt driveways in the cemetery, facilitating observations from a car. The car served as an effective blind, since the squirrels were accustomed to numerous vehicles in the cemetery. It was often possible to drive to within ten yards of a squirrel without disturbing its activity.

Observations were made with $7 \times 35$ binoculars. Behavior types were recorded, when possible, on movie film. Still pictures were also taken.

Study Dates and Times of Observations

This study was initiated on 25 February, 1969, and concluded on 22 November, 1969. This period began prior to emergence of the first squirrel from hibernation in the spring and ended with the entrance into hibernation of the last squirrel in the fall. Approximately 150 hours were spent observing the squirrels in the field. They were studied at 
various times of the day, at an average of four hours per observational day. Observations were made as early as 6 AM and as late as 7 PM. 
CHAPTER III

\section{OBSERVATIONS AND RESULTS}

\section{Individual Behavior}

Individual behavior is considered here as behavior which usually does not involve the active participation during any phase of it by two or more squirrels. This type of behavior is associated with the mainterance of the individual.

\section{Investigarive Behavior}

Scott (1958) described jnvestigative behavior as ". . any kind of sensory investigation of the environment." Investigative behavior may be divided into two categories: day-to-day explorations of the environment for the requirements of the individual, and positions of alertness assumed by the squirrel in response to a disturbance.

The daily exploratory behavior consists of random movements, often in search for food. The squirrel will walk in grass at a relaxed pace, stopping when a food item or object worth investigation is encountered. When the squirrel has finished feeding or investigating, it continues walking, often in a different direction. 
Balph and Stokes (1963) described the posture of the Uinta ground squirrel (Spermophilus armatus) when an individual approached an unfamiliar object, usually inanimate. The squirrel would approach it slowly with its body elongated, finally stopping with one foreleg off the ground. The thirteen-lined ground squirrel exhibits behavior similar to that of the Uinta ground squirrel. When an individual approaches an unfamiliar object, it moves cautiously, one foot being slowly moved forward and placed down, then another foot. The neck is held out in the direction of the object. When the investigation is of an intense nature, the tail may be held in a "bristled" position, with the hairs standing out at right angles to the tail, resembling a test-tube brush. The amount of tail-bristling apparently indicates the intensity of a drive (Grubitz, 1963) in investigative, sexual, and agonistic behavior. If the hairs on the tail are flat, the drive of the individual is not as intense. Alert postures are assumed by squirrels when a stimulus elicits curiosity. The intensity of the disturbance and the range of the animal's vision may cause squirrels to assume a variety of postures, which form a continuum. The postures which seem to indicate a greater alertness may simply be an attempt by the squirrel to extend its field of vision. 
Postures may be classified according to intensity and whether the squirrel is walking, sitting, or standing (Figures 1, 2, and 3). The tail is used for balance in the standing positions.

Alert positions were assumed by squirrels on various grave markers in the cemetery at all times of the year. These positions were not elicited by the presence of an observer, but seemed to be an attempt to extend the field of vision and permit investigation of a larger area.

\section{Ingestive Behavior}

Ingestive behavior includes feeding, drinking, and any activities pertaining to finding food or water.

During the course of the study, no individual was seen drinking. However, the cemetery was often watered, and after rains, pools of water often formed in the roads, providing a source of water. Also, at least two water faucets per acre were present, which often dripped. Early morning dew also provided a source of drinking water. Much of the necessary moisture may be contained in the vegetation consumed by the squirrels.

Foraging constituted a large part of a squirrel's feeding activity. The squirrel would forage by walking at a relaxed pace, apparentiy at random. When a food item was encountered, it would stop and feed. After an item was 


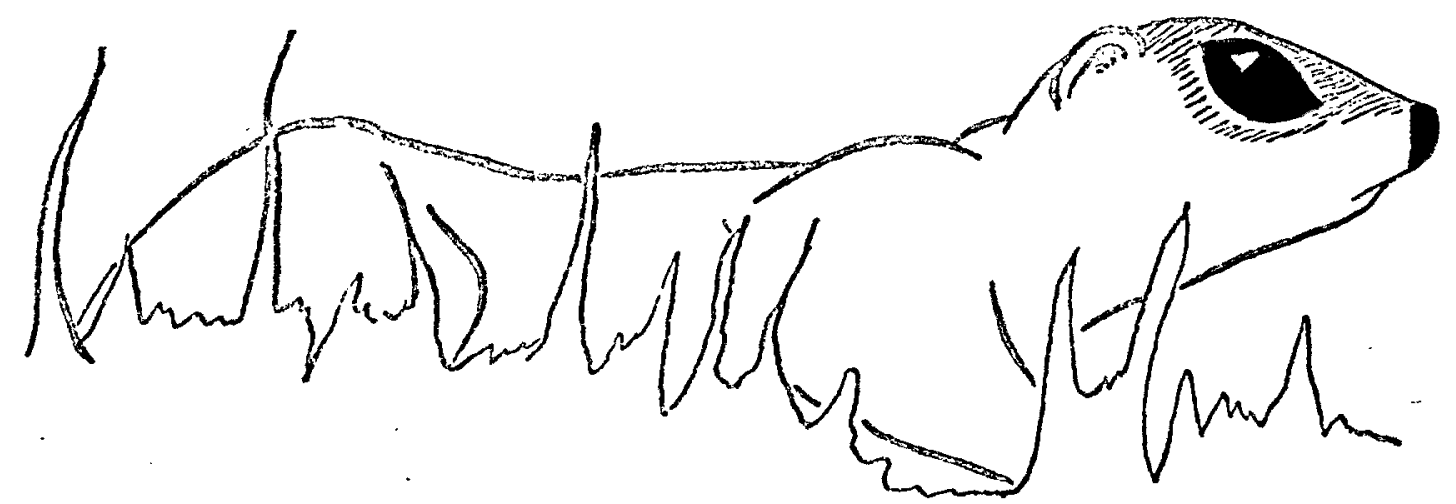
Fig. I--Investigative alert posture assumed while
walking, head upraised. 


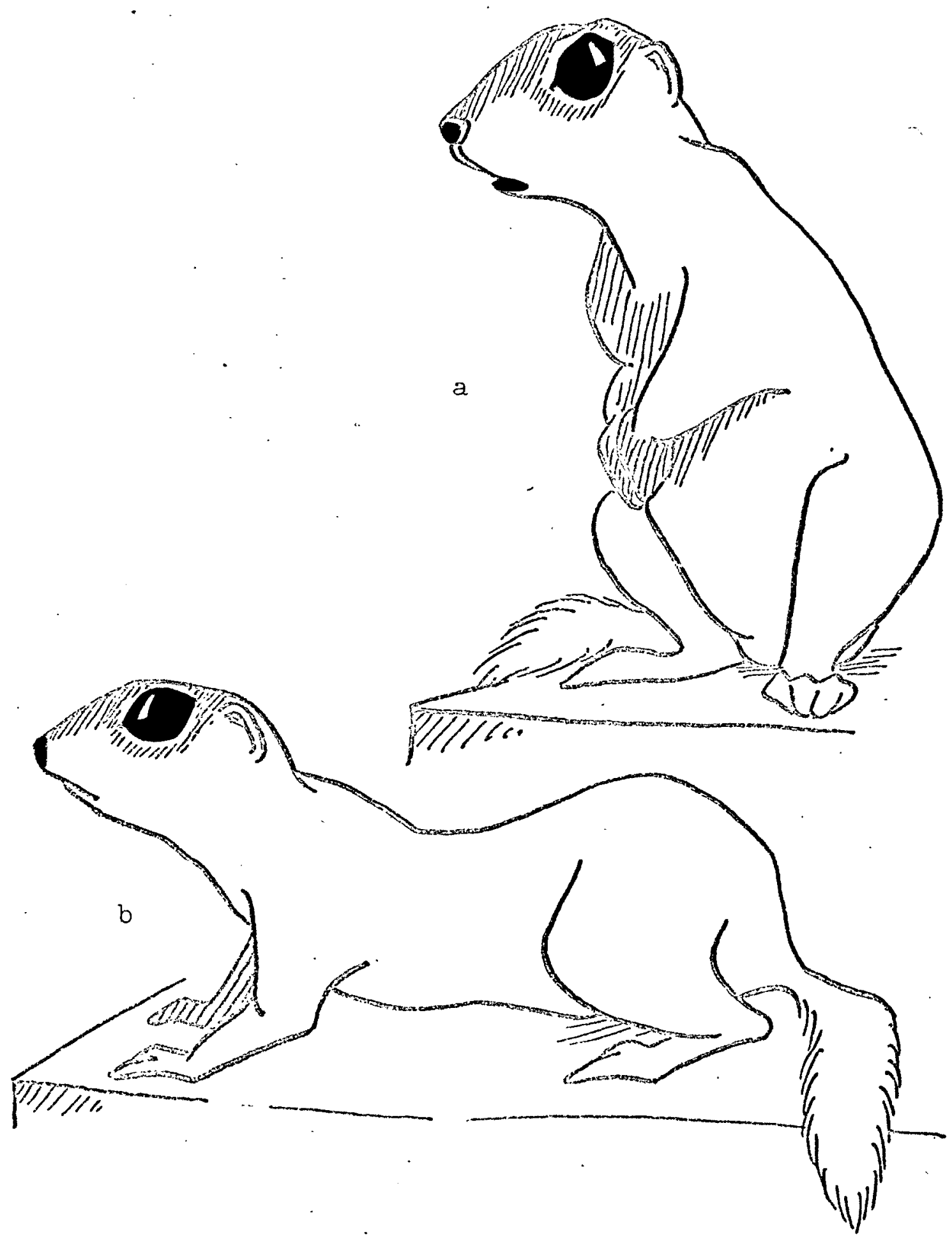

Fig. 2--Investigative alert postures assumed while: squirrel is sitting. a, sitting on sacral region; b, sitting on hindlegs. 

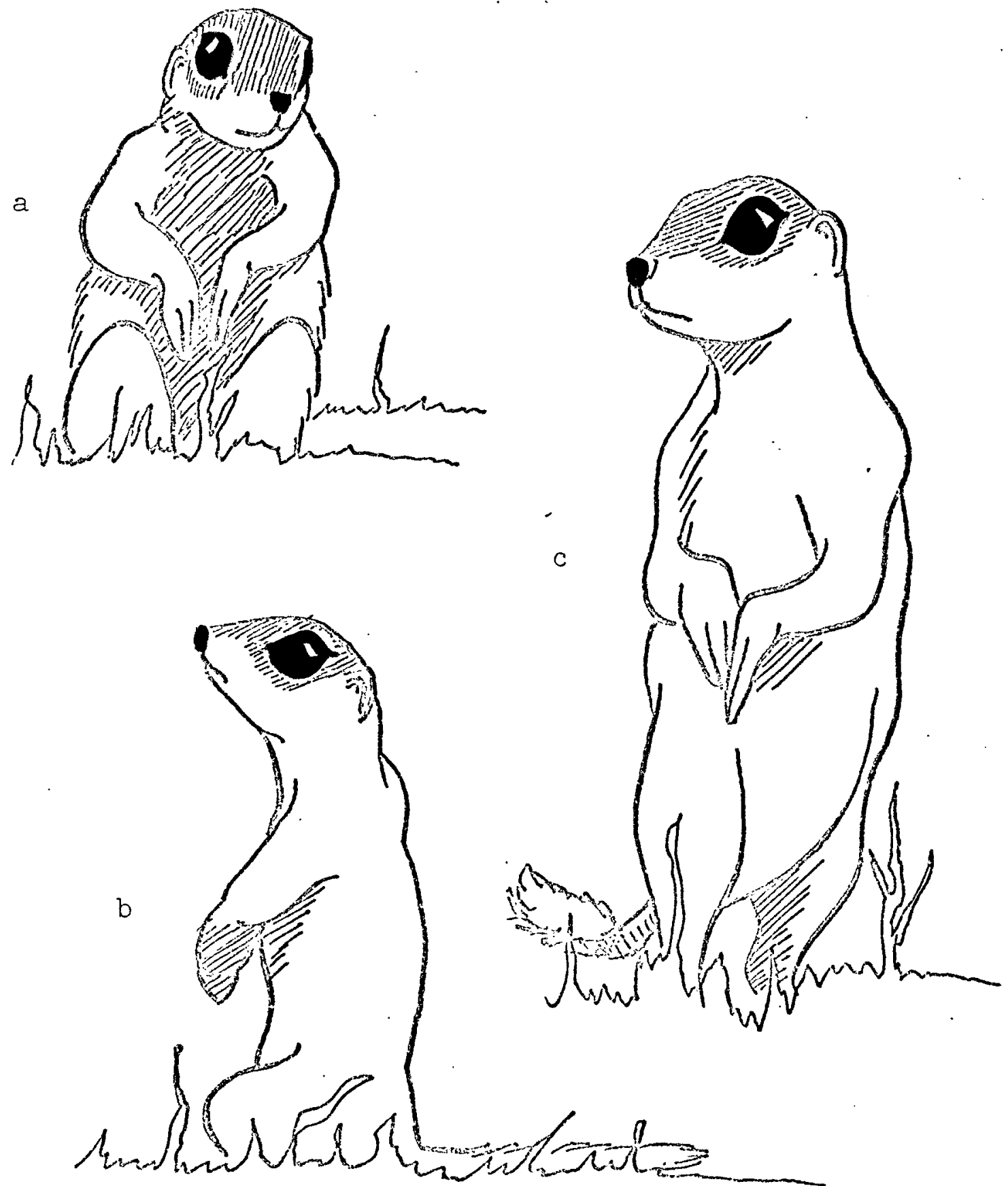

Fig. 3--Investjgative alert postures assumed by a squirrel when standing. a, hunched alert posture; b, upright alert posture; c, extended upright alert posture. 
consumed, the squirrel usually continued foraging, in the same or a different direction.

Thirteen-lined ground squirrels feed in a variety of positions; these rarge from their normal walking position to the extended upright alert position (Figure 4a, b). Feeding was most often done in a sitting, hunched position (Figure 4c). The forepaws are often used to manipulate the food item. Ingestion in an upright alert position was used by squirrels to reach the ends of higher grass stems or extend their field of vision while feeding. Forepaws were often used to reach up to taller grass ends from the upright position. If an individual was frightered while feeding, it would often carry the food item in its mouth into the burrow.

Grubitz (1963) reported ground squirrels in an enclosure building food caches in the dirt and storing food in burrows. Hoarding in burrows has been observed, but no squirrels in the cemetery were seen storing food in above-ground caches. The cache-building may have been due to an increased density of squirrels in the enclosure.

Seeds and stems of the various grasses present, flowers and stems of dandelions, and insects constituted the major food items of the ground squirrels in the cemetery. Grasshoppers were the most desirable insects. Squirrels were 

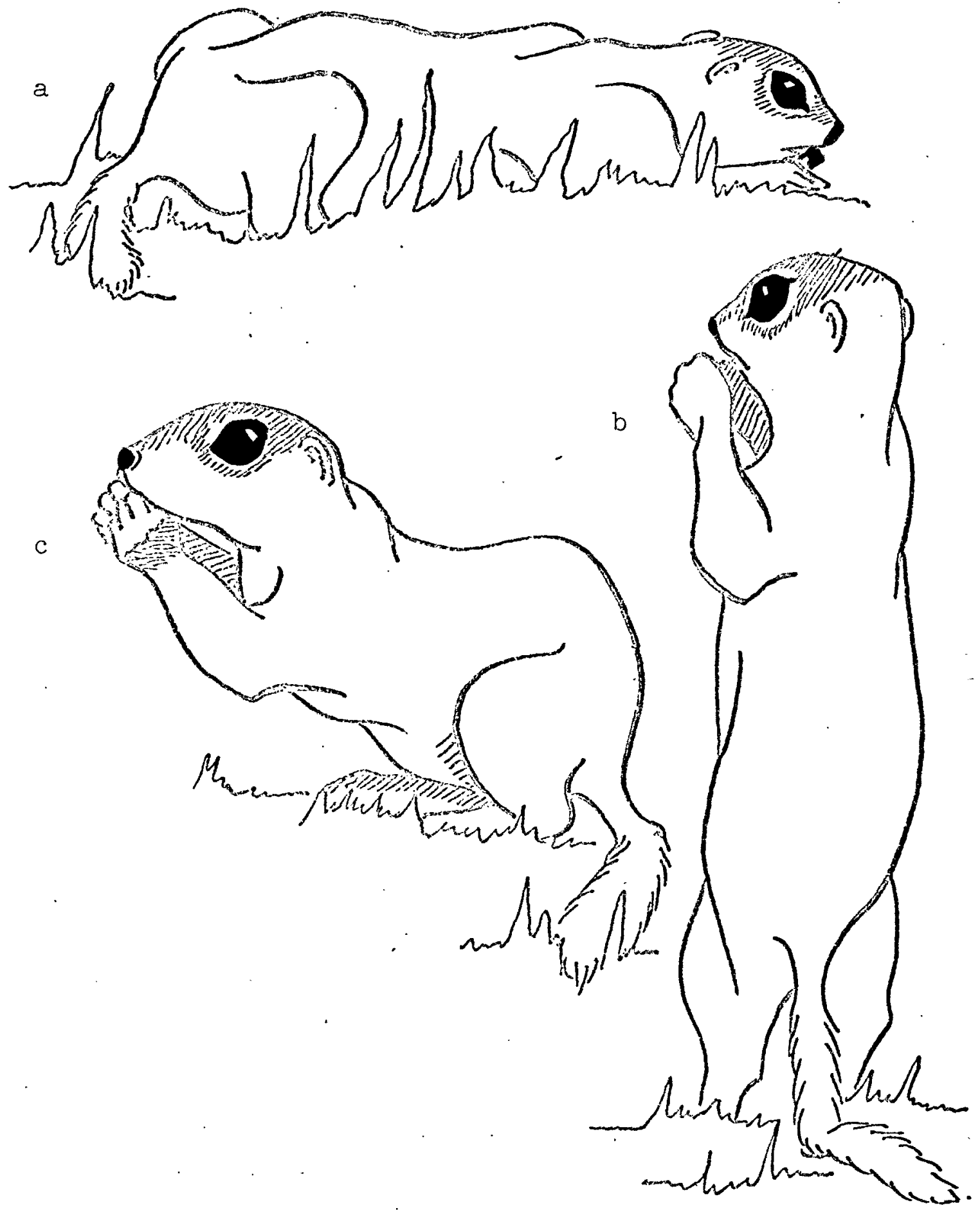

Fig. 4--Feeding postures. a, feeding while walking; $b$, feeding in upright alert posture; c, normal feeding : position, hunched over. 
often seen carrying pecans to their burrow and shelling them next to the burrow entrance.

On 27 September, a juvenjle ground squirrel was observed feeding in an upright position on a freshly killed young blue racer (Coluber constrictor). When the squirrel was approached in a car, it ran twenty-five feet to its burrow entrance with the snake in its mouth. The squirrel became frightened and dropped the snake. About one-third of the anterior end of the snake had been consumed, and the tail was still moving weakly. Predation upon vertebrates is not unusual in various species of ground squirrels. Bailey (1923) and Green (1925) reported predation by squirrels on chickens, and turkey predation was reported by Cook and Henry (1940). Bailey (1893) mentioned predation on mice; Bridgewater and Penny (1966) reported predation on cottontails (Sylvilagus floridanus), loggerhead shrikes (Lanius ludovicianus), and six-lined racerunner lizards (Cnemidophorus sexlineatus); and Cameron (1967) listed predation on deer mice (Peromyscus maniculatus) and yellow pine chipmunks (Eutamias amoenus). However, no records were found of ground squirrels eating snakes.

\section{Grooming and Comfort Movements}

The squirrel might groom itself at any time of the day at any place in its home range. Squirrels would often 
interrupt an activity to groom, but usually concerned themselves with only one body location, rather than the entire body. There was no particular sequence of grooming of one body area following another. Instead, squirrels only groomed areas that warranted attention at a particular time. Squirrels would groom themselves intensely after being marked with fur dye.

When squirrels groomed for a period of time, they usually assumed a sitting position, resting on the sacrum. Squirrels washed with their mouth and moistened forepaws. The squirrel would wash its head and body areas, such as the sides or belly, by licking the forepaws and drawing them over or rubbing them into the area being groomed. The squirrel would often lick its belly, especially near the genital region, and its sides. Grubitz (1963) pointed out that, in washing the head, squirrels always drew the forefeet from behind the ears forward to the nose. Forelegs and hindlegs were groomed by licking. Sometimes a forepaw was used to aid in cleaning other legs. The tail was washed by pulling it through the mouth, starting at the proximal end and terminating with the distal end.

$$
\text { Claws were occasionally "picked" by a squirrel, }
$$
usually after it had been grooming for a few minutes. It 
placed a claw in its mouth, pulled it out, then placed another claw in its mouth. The claws apparently were pulled between the upper and lower incisors.

Scratching was done by using the hindlegs or the mouth. The hindlegs were used to scratch the sides or the head. For other regions, the squirrel would usually bite the area gently with its incisors.

Dusting was occasionally observed in the ground squirrels. They used sandy areas, especially gravesites with sand placed over them, or the dirt roads in the cemetery. A uniform pattern was followed in dusting. The squirrel would place its nose in the sand, then move forward quickly for a distance of about one foot. This served to throw sand upon the animal, which it promptly shook off. Dusting might be repeated a number of times.

Ground squirrels often stretched during their daily activities. Stretching consisted of elongating the body and flattening it against the ground, with the back forming a concave arc. The tail was extended straight out, and the hindlegs stretched out. The head was then extended, followed by a foreleg stretched out (Figure 5). The squirrel usually remained in this extended position for two to three seconds, paused, then continued another activity. The tail nay or may 


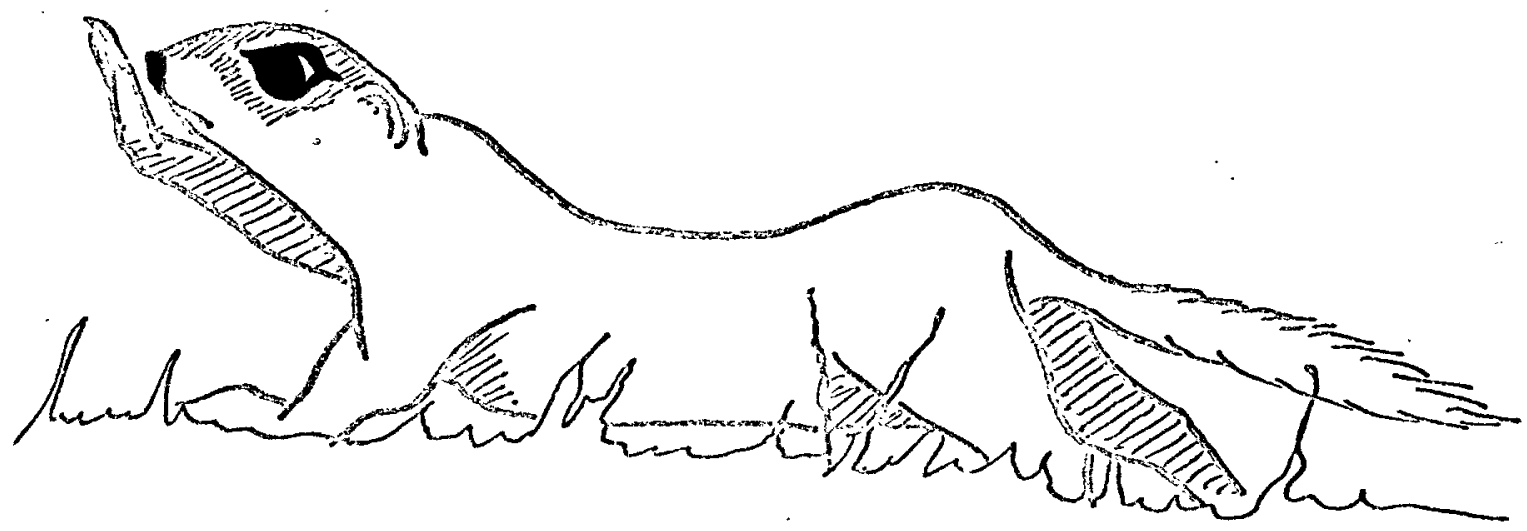

Fig. 5--Stretching position 
not be bristled during stretching. The sequences are similar to those described by Grubitz (I963).

\section{Thermoregulatory Behavior}

Animals may, by seeking out favorable situations, affect some control over body temperature. This is not as important in homeothermic animals such as the thirteen-lined ground squirrel as it is in poikilothermic animals.

Ground squirrels do react in certain ways to temperature extremes. The most documented example is hibernation, which is influenced by many factors other than cold temperatures. No correlation of time of emergence from hibernation in the spring with soil temperatures is found in north Texas in a previous study. Hibernation is controlled primarily by an endogenous cycle (Pengelley and Fisher, 1963). The activity of ground squirrels, howeven, does correspond to temperature. On cool days, ground squirrels stay in their burrows longer and spend less time above ground than on warm days. When the daily temperature exceeded 90 degrees Farenheit, the squirrels were active in the early morning and late in the afternoon, but were kelow ground at mid-day. These patterns were also reported by NicCarley (1966) in a population of thirteen-Iined ground squirrels 30 miles east of the primary study area. However, there were exceptions. A few squirrels 
could be seen out early on cold mornings, and in the summer, some fed at mid-day, even when the temperature exceeded I00 degrees Farenheit.

Ground squirrels also adjusted their above-ground activity to seek out favorable situations in hot weather. On extremely hot days, most ground squirrels fed in the shade of grave markers and only occasionally ventured out into the sun. On I5 July, at 3:45 PM, with a temperature of 104 degrees Farenheit, a wet ground squirrel was seen feeding next to a water sprinkler. No attempt was made by the squirrel to avoid the water. Numerous other squirrels were observed feeding at this time, mostly in the shade.

\section{Shelter-seeking and Orientation}

During the course of their daily activity, ground squirrels were always aware of their position relative to all burrows in the vicinity. When surprised, squirrels ran immediately to the nearest burrow entrance. The movement was usually quick, with the squirrel running at maximal speed. They cften paused next to the entrance before entering. The burrow provided safety for the squirrels from all predators in the cemetery. In other regions, however, the burrow offers little protection from digging predators, such as the badger (Taxidea taxus). 
After being noosed, ground squirrels were usually released in the capture area. They would stop quickly upon release, then make a quick dart for a burrow. If the ground squirrel was moved a distance away from the capture site or was confused as to its whereabouts, it ofter would run rapidly in a random direction for a few yards to escape its captor. The squirrel then froze, trying to avoid detection by flattening its body against the ground. The color pattern of brown and white stripes and spots usually made it difficult to see a squirrel against a grassy background, once it became motionless. After the immediate danger passed, the ground squirrel oriented itself and moved cautiously toward its home range.

Two squirrels might seek shelter in the same burrow, but this was seen only during sexual behavior.

\section{Burrows and Digging}

Ground squirrels excavated burrows throughout the nonhibernating portion of the year. There seemed to be peaks of burrow-digging activity just after emergence from hiberration, just prior to entry into hibernation, and while litters were below ground in the late spring and early summer. Very few juveniles were observed constructing burrows after dispersal from the nest. 
In digging, a squirrel used its forepaws to claw at the dirt and its hindlegs to kick it away from the site of digging. Every few minutes, it pushed a load of dirt to the surface with its forepaws and forehead and scattered it. McCarley (1966) reported that squirrels used their hindfeet to scatter dirt away from the burrow entrance and tamp dirt with their foreheads to make it level with the ground surface, but this was not observed during this study. After a rain or watering, the dirt around the burrow entrances disappeared and the burrow was concealed to some extent by grass. Often squirrels would start burrows and leave them incomplete after digging only a few inches. Evans (1.95I) estimated that a single squirrel dug three to four burrows per year in Michigan. Much evidence of burrow digging by squirrels was seen in the summer prior to litter emergence. At the Biological Station, females which were not pregnant or nursing litters, also engaged in this activity. This may be a form of adaptive behavior to provide burrows for dispersing juveniles. Desha (1966) found that, after dispersal, 11 out of 13 juveniles occupied burrows previously dug by adults.

Three types of burrows were described by Rongstad (1965); these were nesting, hiding, and hibernating burrows. It was not feasible to excavate burrows on any of the study areas 
to study structure, but burrows were used for all three purposes on the cemetery. Desha (1966) reported that, in southern Oklahoma, 78 per cent of the burrows were hiding burrows and 22 per cent were nesting burrows. He also suggested that nesting burrows were used as hibernating burrows in southern Oklahoma, since they were located below the frost line.

Size of burrow entrances varied, ranging from less than two to more than six inches in diameter. Many burrows have more than one entrance.

Three areas of the cenetery were particularly utilized for burrow construction. The majority of burrows were constructed in grass near tombstones. The second most preferred site was under grave markers. Finally, some burrows were constructed in the sand that was placed upon gravesites. These were not surrounded by vegetation and consequently, were not concealed. Very few burrows were found in the areas of the cemetery where no markers were present. Squirrels in the cemetery showed a marked preference for areas with grave markers, even if the markers were small and flat.

At the North Texas State University Golf Course, a female was found to have a litter in a burrow at the base of a tree. The tree was partially hollowed, but whether the burrow extended up into the tree was not known. 
All burrows might be used by more than one squirrel for hiding purposes. However, only one squirrel at a time would normally be present in a burrow. On only two occasions, both during courtship, did more than one squirrel enter a burrow for shelter-seeking purposes. Squirrels would occasionally abandon nest burrows, and these in turn would be re-occupied by other squirrels.

The burrow is plugged to a depth of one to three feet at the beginning of hibernation in the fall (Rongstad, 1965). In the cemetery these plugs often rcached the surface and were level with the surface of the burrow entrance.

\section{Nest-building}

Nest-building activity was carried on throughout the non-hibernating period of the year, but was especially evident after spring emergence, during litter nursing, and just prior to entrance into hibernation.

Construction of nests involves collection of grass and carrying it to the burrow. Squirrels gather grass in their mouths, often using the forepaws to aid in collection, then returned to the burrow. Squirrels usually returned to the surface quickly after entering the burrow with nest material. Grass was collected adjacent to the nest burrow and up to 
30 to 40 feet away from the entrance. Squirrels seemed to show a preference for dry, dead grass.

In a previous study, utilizing an outdoor enclosure with nest boxes, the structure of nests was noted. Squirrels usually utilized live grass in construction, since little dead grass was available. Bits of trash, such as fiberglass insulation material, were also found in the nests. The materials were usually constructed to form a round ball with a hollow center. Some nests, however, consisted of a flat layer of material, on which the squirrel lies. Similar nests were described for the Mexican ground squirrel, Spermophilus mexicanus (Edwards, 1946).

\section{Locomotion}

Loconotion is the active movement of an animal through space. Two types of locomotion are considered here--walking and running.

Walking.--The primary mode of locomotion in the thirteenlined ground squirrel is walking. Bisenberg (1968) describes walking by Peromyscus as a ". . crossed extension pattern - . where the contralateral limbs are in synchrony. . ." This is the same pattern found in the thirteen-lined ground squirrel. 
While walking, a squirrel may assume one of three positions. The first, a body-elevated posture (Figure 6a) is generally used whice feeding or investigating. The animal walks with its body raised off the ground, the tail usually being held horizontally about one-half inch off the ground. The squirrel usually walks in sporadic spurts, and the walk may be either fast or slow.

Another position, the body-hunched posture (Figure 6b), is used primarily for feeding. The squirrel has most of its body flat on the ground, except for the rump, which is elevated. The tail is dragged along the ground.

The third walking position, slinking (Figure 6c), is used by disturbed squirrels. The body is held flat on the ground, siightly expanded laterally, with the back slightly coricave. It moves in short, rapià spurts, often lifting its head in an investigative action. This type of walking allows the squirrel to move without being easily detected.

Running.---Eisenberg (1968) described a type of locomotion as a ". . quadrupedal ricochet where the forelimbs and hindlimbs strike the ground alternately." The thirteen-lined ground squirrel runs in this manner, often with a leaping motion. When initiating a run, a ground squirrel may or may not flick its tail. Upon terminating a run, the squirrel 

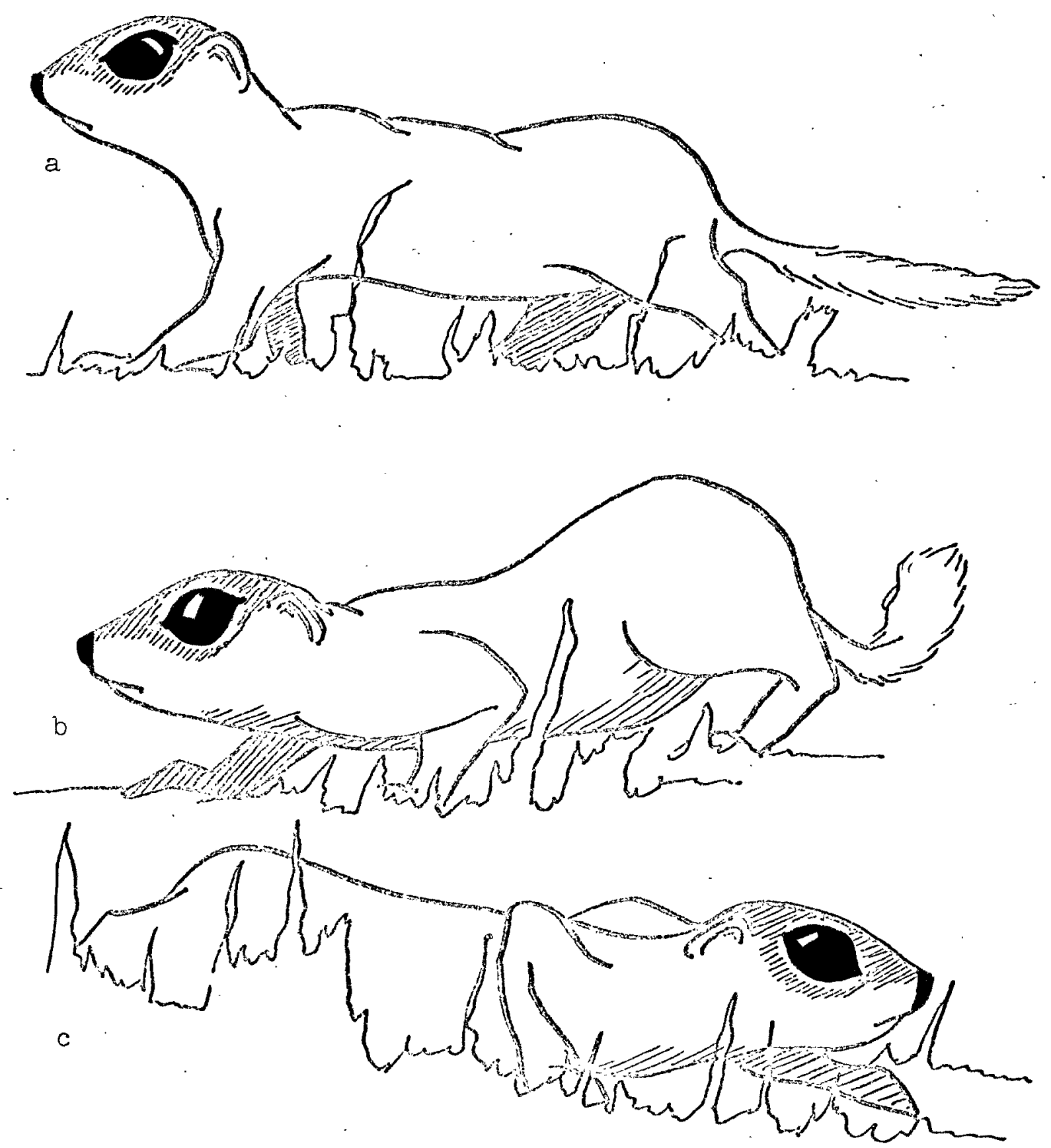

Fig. 6--Walking positions. a, body-elevated posture; b, body-hunched posture; $c$, slinking posture. 
usually flicks its tail over its back or waves it in a circular arc.

Running may occus in short, two- to three-yard spurts, or for longer distances, running up to 20 yards continuously. For running longer distances, the squirrel uses a slower, loping motion. Running may consist of a straight line or zig-zag route of travel. After a run, a squirrel would assume an alert position, often an upright alert posture. Ground squirrels were found to cover large distances in short periods of time. On one occasion, a male was sighted (during courtship) an estimated 250 yards from where it had previously been seen, 55 minutes earlier.

\section{Tail-filicking}

Tail-flicking is a quick up-down motion of the tail, beginning with the tail held horizontally to the ground. Tail-flicking may occur when the squirrel is in an upright or walking position (Figure $7 a, b$ ), and may be initiated more than once.

Balph and Stokes (1963) suggest that tail-flicking is a form of communication which functions to enable other squirrels to identify a movement by another squirrel as being of the species and not presenting a potential danger. In the cemetery, tail-flicking did not occur immediately after 
31

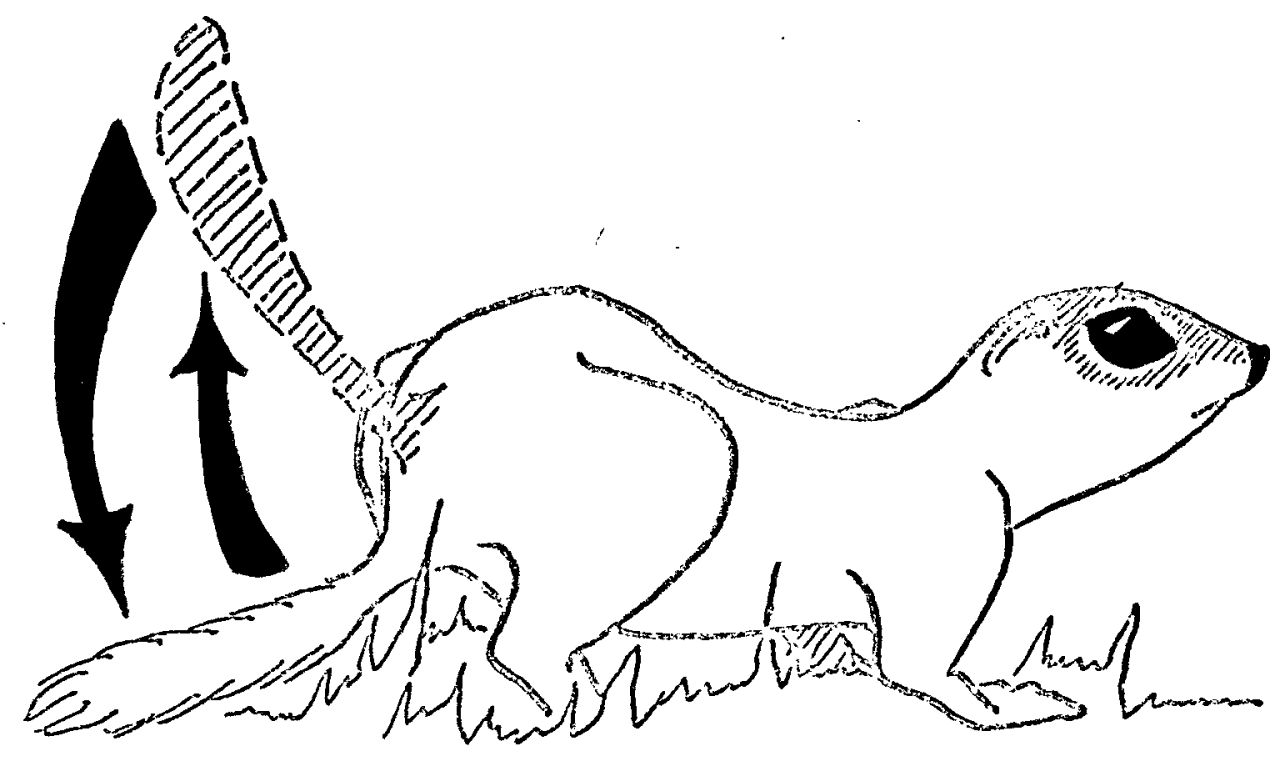

b

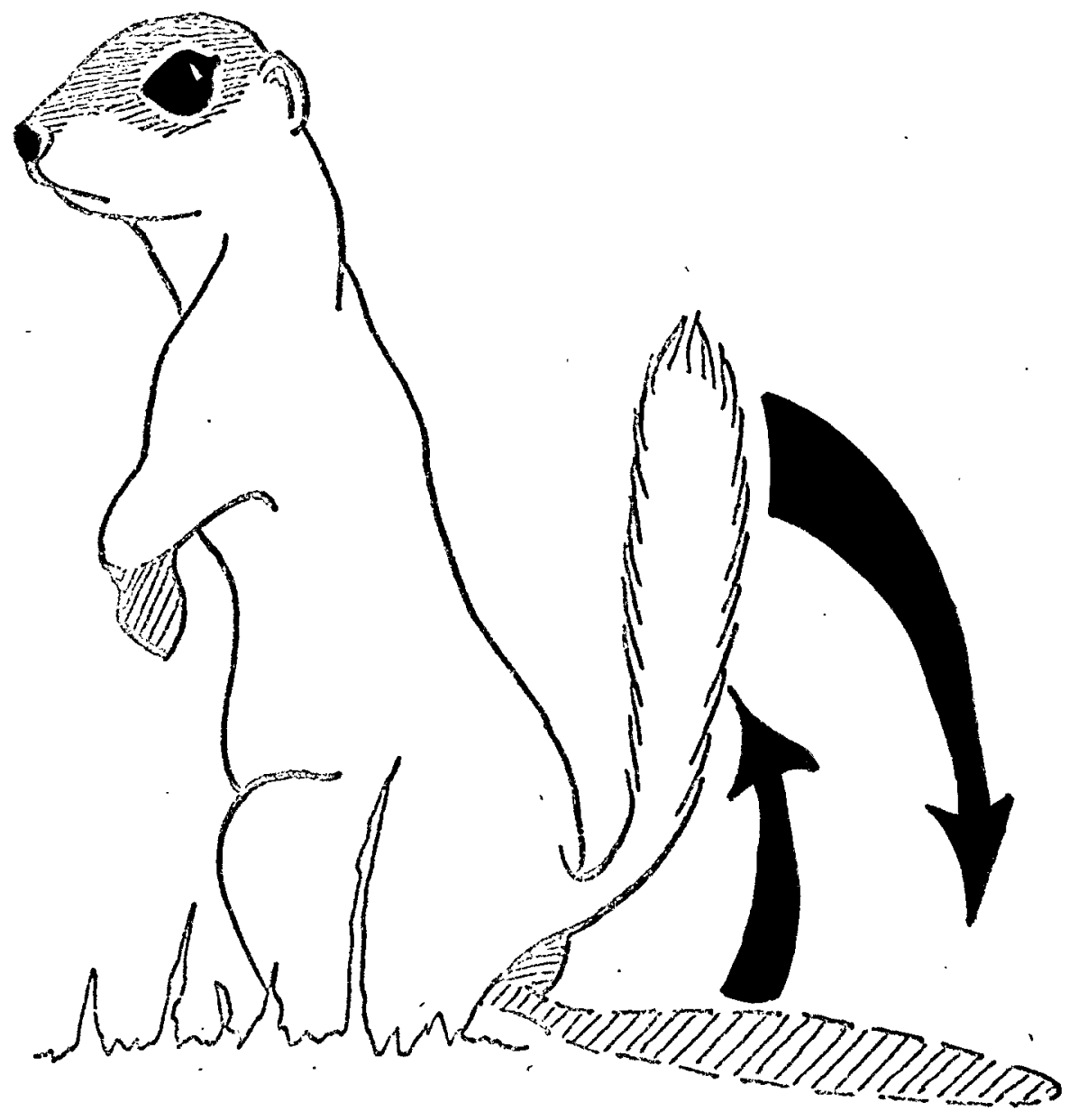

Fig. 7--Examples of tail-flicking. a, tail-flicking in a walking position; b, tail-tlicking in an upright alert posture. 
emergence from hibernation. Only six instances of tailflicking by four squirrels were seen prior to I April, 27 days after emergence of the first squirrel from hibernation. With the onset of courtship and the appearance of more squirrels in the cemetery, the amount of tail-flicking increased considerably. This indicates that tail-flicking increases in intensity as the density of squirrels and the amount of individual contact increases, thus serving a communicative function.

\section{Social Behavior}

Social behavior is that behavior which requires active participation of two or more animals during some portion of an activity. This activity may be directed by one animal at another, or it may be reciprocating actions. The thirteenlined ground squirrel is not a social animal, except during courtship and rearing of litters. McCarley (1966) indicated that thirteen-Iined ground squirrels are drawn together into colonies bit $a$ common habitat preference rather than by attraction to other squirrels.

\section{Agonistic Behavior}

Scott (1958) described agonistic behavior as "Any sort of adaptation which is connected with a contest or conflict 
between two animals. . ." Agonistic behavior in thirteenlined ground squirrels is expressed in different patterns, depending on sexes inrolved (male-male, male-female, or female-female) and the time of year. In a natural situation, such as a cemetery or golf course, agonistic encounters are not common. Only 19 agonistic encounters were observed during the nine months of the study. Balph and Stokes (1963) suggest that squirrels apparently avoid each other and usually remain at a distance from each other that is greater than the individual distance (Hediger, 1950).

Territoriality is limited to the burrow which is defended by the squirrel in possession at the moment. Ground squirrels apparently do not defend areas around burrows, and a burrow may be used by more than one squirrel, provided only one squirrel occupies it at a given time.

Agonistic behavior was found to be variable according to the time of the year. No agonistic behavior was seen during the first month after emergence. The first observed incident occurred on 8 April early in the period of courtship. Of the 19 encounters observed, 15 occurred during the period from 8 to 21 April. Of the remaining four encounters, three were directed at juveniles by adults, and the fourth was a male-female encounter just prior to hibernation. A majority 
of encounters during courtship are probably a result of a male mistakenly courting another male, non-receptive females driving off males, and competition of males for females. In agonistic encounters, the sequence of events is variable. There may be a threat, combat, and chase; combat and chase; threat and chase; combat only; or chase only. Submissive postures seemed to be restricted to females during courtship. This is discussed in the section on sexual behavior.

Threat.--Balph and Stokes (1963) explain the function of threat as being an evolved behavioral pattern which requires less energy output and risk of injury than fighting, but is a means to the same end. Threat was observed only in malemale encounters. In a typical encounter, one male approached another in a posture similar to that of unfamiliar object investigation, with its neck extended and its tail bristled, waving side-to-side slowly. The other male was stationary and assumed an agonistic posture, with its tail also bristled and waving. Its head was extended, held close to the ground as were the shoulders, and its rump was held well off the ground in an arched position (Figure 8). Balph and Stokes (1963) reported that the anal papillae of the Uinta ground squirrel are everted during threat. It is not known whether or not this is true of the thirteen-lined ground squirrel, 


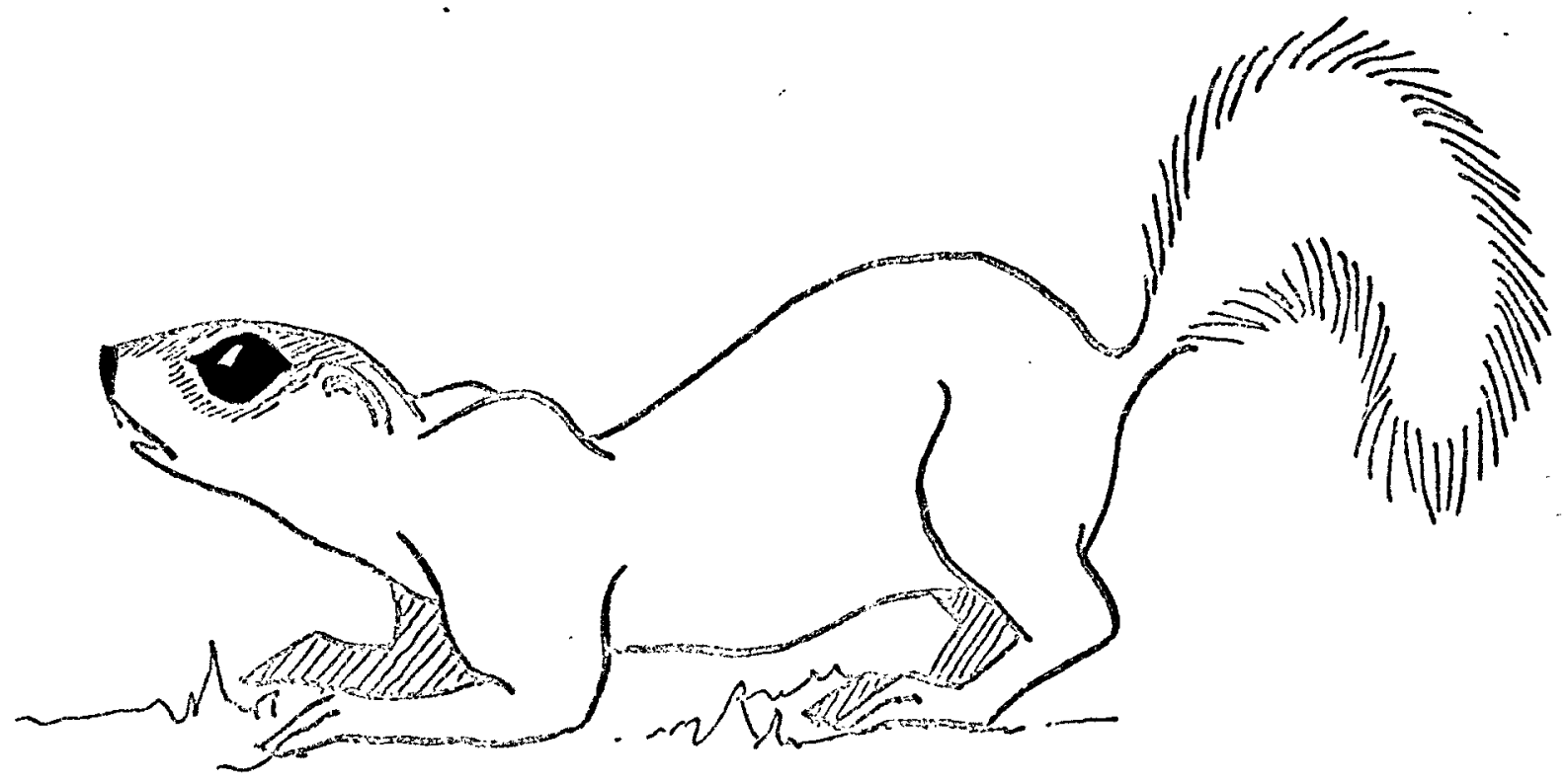

Fig. 8--Agonistic threat posture with tail bristled 
but the papillae are everted when the squirrel is being held by a human.

Combat.-- Very few instances of combat were observed during the study. Combat consisted of thrusts by one squirrel at another, usually directed at the hindquarters. No biting or attempts to bite were seen. Injuries were apparently not inflicted during any encounter. On one occasion, two squirrels, both male, engaged in a circular chase with a maximum diameter of two feet for a period of three seconds. The loser of the battle once jumped eight to ten inches in the air to avoid a thrust by the other. A chase then ensued. Other examples of combat were seen when females drove off males with quick thrusts during the courtship period.

Chase.-- Threat or combat often resulted in a chase, whereupon the defeated or subordinate squirrel ran from the victorious or dominant squirrel. In encounters where the threat posture was exhibited by one squirrel, the squirrel assuming the posture "won" the encounter and the other squirrel ran off. In situations where combat occurred, the victorious squirrel drove off the defeated squirrel and a chase usually ensued. In many encounters during courtship, there was no combat or threat position assumed, but a chase only, initiated 
by an aggressive squirrel running at another. Before bodily contact could be made, the other squirrel ran off. Chases of an agonistic nature observed during the period of courtship were male-male encounters. Male-female chases were observed during courtship, but were of a sexual nature and not agonistic. One male-female chase occurred on 4 October, just prior to entrance into hibernation. No female-male chases were observed, although females did exhibit agonistic behavior toward males. No female-female encounters or chases were seen, but have been previously reported (Grubitz, 1963). The chase consisted of the subordinate squirrel running away from the dominant, usually at maximal speed. The tails of both squirrels are bristled, while the pursued's tail is held arched and often waved side-to-side while running. The chase is usually terminated when the pursuing squirrel stops. In only cre instance was a pursued squirrel overtaken. A quick combat ensued and the subordinate squirrel ran off again and the dominant chased it for another two or three yards. When a squirrel stops pursuit, it usually assumes an upright alert posture. The squirrel being pursued will often assume an upright alert posture also, two to three seconds after the pursuing squirrel stops. It then resumes its activity after moving further away from its pursuer. Once, 
a pursued squirrel assumed an upright position before the pursuant. The pursuant then stopped in an upright position. However, the chase continued when the pursued squirrel began running again.

Chases observed lasted up to 23 seconds, although the average was 4 to 5 seconds. The length of chases was also variable. A short chase, consisting of a short dash, might only last for 3 yards, while longer chases, with very active pursuit, could be in excess of 50 yards. These long chases were not in straight lines, but in zig-zag pattern, with the squirrels often doubling back.

Social hierarchy.--A social hierarchy seemed to exist during the courtship period. Males No. 1 and 4 were apparently dominant over all other males and 4 was subordinate to 1 . All males that No. 1 encountered in its range of vision were chased out of the area during courtship. The same behavior was exhibited by No. 4. Male No. 1 was defeated by male No. 4 in one encounter, but it defeated No. 4 in subsequent meetings. This was not territorial aggression, as these encounters occurred in various places of a squirrel's home range and only during the courtship period. 
Summer agonistic behavior.--Agonistic behavior of adults toward juveniles was seen during the summer. This probably serves as an aid to juvenile dispersal from the litter burrow site. This is discussed in the section on juvenile behavior.

Fall agonistic behavior.--Only one instance of aggressive behavior was observed in the fall, on 4 October, just prior to entrance into hibernation. A male ran at a female who had a burrow ten yards from that of the male. It thrust at the f'emale, causing it to run off to a spot about two yards away. The male then began a series of "foot-stamping" movements. It was in a sitting position and alternately stamped its hindfeet, with its forefeet placed on the ground. Its tail was bristled and slowly moved from side to side. It moved two feet toward the female and continued the "foot-stamping." After seconds, it moved and thrust at the female, whose tail was also bristled. After the thrust, the female ran off two more yards. The male then continued its "foot-stamping" for seconds, then ran to a spot 20 yards away. This "foot-stamping" was described in male thirteen-lined ground squirrels by Grubitz (1963), but it was reported in a section on investigative behavior.

In this situation, "foot-stamping" appears to be a form of displacement activity. Displecement behavior is described 
by Marler and Hamilton (1966) as behavior which ". . Emerges in conflict situations.. . [and has] irrelevance to the immediate context. . In the absence of the customary eliciting stimuli." In this situation, there is an apparent conflict of drives, to attack or to escape, being re-directed into "foot-stamping" in the male.

Agonism toward humans.--When ground squirrels were captured with the noose, they exhibited a typical pattern of behavior. Upon noosing, the captured squirrel usually gave a distress call, similar to a "scolding" call of a bluejay (Cyanocitta cristata), and its tail was bristled. A few squirrels emitted a trill call, similar to the alarm call of a killdeer (Charadrius vociferus). These calls are probably a response to predation since similar sounds have been described (McCarley, 1966) when a juvenile squirrel was captured by a roadrunner (Geococcyx californianus). After a squirrel was grasped by its captor, its anal papillae were found to be everted and its tail remained bristled. The squirrel struggled and attempted to bite any object within reach. Squirrels usially defecated upon beirg held, and only rarely did one urinate. This behavior pattern was the same, regardloss of the time of the year, except that the trill was not heard until one month after emergence from hibernation. 


\section{Sexual Behavior}

Activity which". . includes courtship, coition, and any related behavior" is considered as sexual behavior (Scott, 1958). McCarley (1966) described courtship and breeding in the thirteen-lined ground squirrel, but did not observe a complete sequence from initjation to termination.

Sexual cycle.--Upon emergence from hibernation, males had testes descended into the scrotum. McCarley (1966) reported that the estrous cycle oi females began during the second week in April. He also stated that the earliest conception date (estimated) was 10 April and the latest was 22 June. Intercourse was first observed in the cemetery on 8 April. Bridgewater (1966) set the estrous period of the thirteen-lined ground squirrel at 27 days, and McCarley (1966) allowed one month between birth date and the date of emergence of the litter above ground. During this study, the first litter emergence was observed on 17 June and the last on 28 July. Based upon the data of Bridgewater (1966) and McCarley (1966), the estimated dates of conception were 20 April and I June, respectively.

Behavior.--With the onset of sexual behavior, the number of agonistic encounters increased, especially between males. 
Males were seen, on occasion, driving off a courting male, as it prepared to mount a female. Conversely, some males dismounted a female in order to drive off another male which ventured too close. Dominance was apparently evident in male squirrels at this time (see Agonistic Behavior). Certain males, which are especially aggressive toward other males, may contribute more genes to the gene pool than the less aggressjve or subordinate males, which are often driven away from females.

There was a corresponding increase in male investigative behavior with the beginning of courtship. Males actively sought out fernales. During this period, males often covered long distances in a short time.

A male in an unfamiliar area exhibits a nervous investigative behavior, walking and running in quick spurts, with much tail-flicking. They often stop to investigate burrow entrances. When a male is in a very familiar area, a different form of sexual investigative behavior is seen. The squirrel usually runs in a slow, loping motion, often abruptly stopping to investigate burrows. Its tail is bristled during burrow investigation. The male might enter the burrow partialiy, but would back out. The male apparently knows where most burrows are located, and may locate female burrows by 
scent. Some males make regular patrols of an area. On one occasion, one male confined his activity for one hour to a 25-yard by 25-yard area. It searched the area constantly, moving about the area in a clockwise direction, and running off other male squirrels. The male circled the area a number of times. Males would often climb up on tombstones in an apparent attempt to sight females. Squirrels appear to be able to distinguish sexes from a distance most of the time.

Females did not exhibit the marked change in activity levels evident in males, but an increase was noted. Nonreceptive females would often display agonistic behavior to courting males and drive them away.

Various patterns of courtship were observed, but usually they followed a general pattern of the male actively seeking out a female, a chase, olfactory exploration, assumption of a receptive (submissive) posture by the female, followed by mounting and coition.

A typical courtship and mating encounter with most of the sequences present is described as follows. A male spotted a female and approached the female in a slinking movement, flicking its tail. They stretched toward each other with tails not bristled. The female then flicked her tail and ran to a spot 15 yards away, followed immediately 
by the male. Upon arrival of the male, the female ran another 15 yards. The male hesitated for a second, then followed the female to the next spot. The male flicked his tail twice upon arrival and approached the female slowly, with its body in a stretched slinking position. The female then ran to another point about two yards away. The male walked slowly over to the female, flicking its tail three times. The female then assumed a receptive posture (Figure 9) with its body flattened, head and genital region raised off the ground. The male proceeded in olfactory exploration of the genital region of the female after she assumed the receptive posture. The male did not immediately mount, but walked around within three feet of the female for about 35 seconds. The receptive posture was continuously maintained by the female. The male then mounted and initiated hip-thrusting movements, intromission apparently being effected. The male grasped the skin of the female's back near the thoraciclumbar junction. The male also held the female with the forelegs around the lower abdominal region of the female. The female apparently attempted to keep both squirrels balanced during mounting and intromission, but they often rolled over on their sides, usually on the right side. The tail of the male was bristled. During intromission, the female held her 


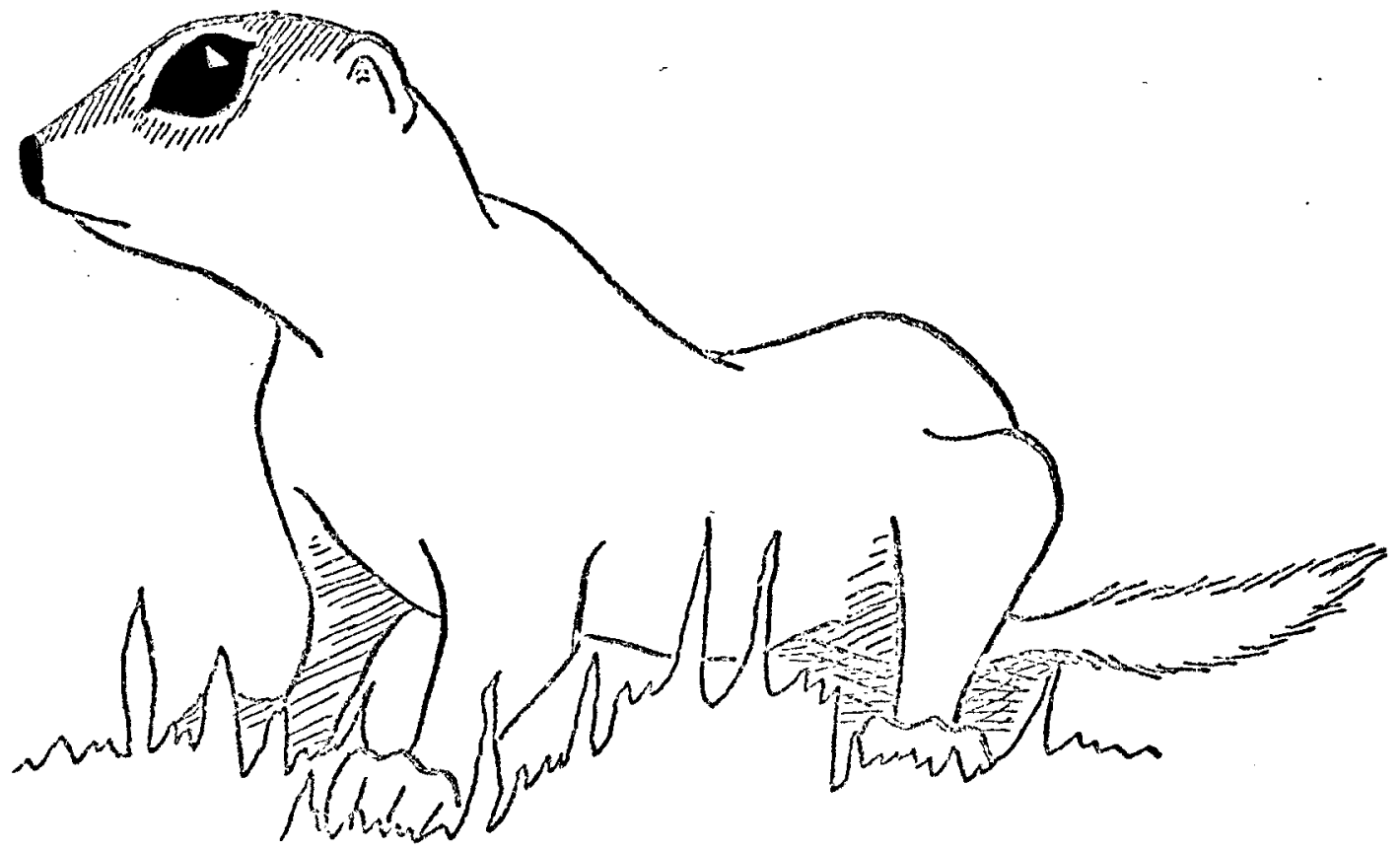

Fig. 9--Female receptive posture during courtship just prior to mounting by a male. 
head high in an alert position. The hip-thrusting movements, which lasted 25 seconds, terminated with the appearance of an unmarked squirrel, probably male, within 5 feet of the pair. The male dismounted and ran off the other squirrel, tails of both being bristled. The female ran back to the point where she was first contacted by the male, apparently her home burrow. The male returned soon to the spot where coition occurred, probably to re-mount the female. This typical sequence is not always followed. Females often assumed a receptive position upon approach by a male, and they would effect coition without prior courtship, except for olfactory investigation by the male.

Hip-thrusting movements have been observed for periods up to two minutes in length. The male usualiy has its tail hairs bristled; the female's tail hairs are usually flat. They may or may not flick the tail during courtship. It is primarily the male that engages in tail-ficking. During the chase, squirrels may run in a zig-zag pattern or a straight line, usually not at maximum speed. The dismounting by males to drive off other squirrels is common, and attempts may or may not be made to remount.

"Kissing" by a male and female was observed once during courtship. The male and female opened their mouths and made 
oral contact. This was also reported by Grubitz (1963) and is similar to the "identification kiss" of the black-tailed prairie dog (Cynomys ludovicianus), described by King (1955). Balph and Stokes (1963) suggest that copulation may occur in burrows of the Uinta ground squirrel. This may be a possibility in the thirteen-lined ground squirrel. On 21 April, a male and a female were startled while the male was preparing to mount the female. They both went into the same burrow, the female first. After two minutes, the female returned to the surface, saw an observer, and went back into the burrow. When the burrow was checked, the entrance was found to be sealed with dirt. A similar instance was noted on 8 April. Desha (1966) reported instances where a male and a female entered the same burrow when frightened during copulation.

\section{Maternal Behavior}

Maternal behavior consists of the care given to the young by the female parent and includes prenatal and postnatal care. In this study, only the above-ground postnatal care is considered.

After the young emerge from the nest burrow, the female fed near them and restricted its activity to their general vicinity for the first few days. 
Females gave varying responses to distress trills emitted by juveniles captured by a noose. The female would usually approach within 10 to 15 feet, then turn and run away, often stopping and assuming an upright alert posture. On one instance, a female approached within five feet of the observer when a simulated distress call was given. As the intensity of the simulated call increased, the female approached closer. One female responded to a simulated trill by emitting an alarm trill similar to the distress trill, but of a higher pitch (McCarley, 1966) and of 1.5 seconds duration. The female faced in the direction of the simulated trill and attempted to locate its source.

Females would occasionally exhibit agonistic behavior toward juveniles of their own litter. If a female wanted to feed in an area where a juvenile was present or if a juvenile approached, the female would make nose-to-nose contact with the young squirrel, followed by a quick thrust. The juvenile usually ran off a few feet, but no chase was made by the female.

If an observer disturbed a litter, a female might move the juveniles to another burrow. This usually occurred after the first or second disturbance. McCarley (1966) reported that the litters might be moved as much as 300 feet. However, some 
females in the cemetery tolerated constant disturbances and made no effort to move the litters.

\section{Juvenile Behavior}

Juveniles are those squirrels which have not yet entered their first hibernation season (McCarley, 1966). Only aboveground, post-emergence behavior was observed.

Definite changes in behavior patterns were evident from the time a young squirrel emerged from the nest until it became established in a burrow after dispersal. The first litter was seen on 17 June. After emergence, the juveniles stayed within five feet of the burrow entrance, remaining close to each other, and engaged primarily in investigative pursuits. Juveniles were seen feeding 30 to 40 feet from the nest burrow after 7 days and 70 to 80 feet after 10 days. A corresponding increase in orientation of the juveniles accompanied these greater distances. Juveniles removed more than five feet from the nest burrow just after emergence were unable to orient themselves. They immediately adopted a motionless, flattened posture, which with their coloration, formed an effective camouflage. The same posture was assumed by juveniles if they were surprised and not able to reach the burrow. When they assumed this posture, they could easily be picked up by hand, but careful searching was 
necessary to find all juveniles. After juveniles had become familiar with an area, they usually ran for the nearest burrow entrance.

Juveniles adopted many of the same walking, investigative, feeding, and foraging postures of adult squirrels. Many young squirrels would climb on grave markers and assume an upright alert posture.

Only the very young, unoriented squirrels exhibited a defensive posture when teased in the grass by the observer. A juvenile would lay on its back, all four paws spread, with the forepaws held near the sides of the head. The tail is bristled and held between its legs on the abdomen, and the anal papillae are everted. The mouth is held open, exposing the incisors, and the eyes are nearly shut. When teasing stopped, the juvenile righted itself and assumed a motionless, flat posture for camouflage. Older juveniles display agonistic behavior similar to that of adults when handled by an investigator. Juveniles just emerged from the nest burrow offer little resistance to being handled, but usually defecate. A distress trill, similar to a female's alarm trill but of a lower pitch (McCarley, 1966) is usually given off when captured. Juveniles react to both the juvenile distress trill and the female alarm trill by running quickly to the 
burrow, but do not always enter. The same reaction occurred when a simulated distress or alarm trill was sounded by an observer.

\section{Post-emergence Behavior}

Ground squirrels exhibit patterns of behavior up.to 10 days after emergence from hibernation that are distinct from those of other times of the year. The first squirrel in the spring was seen on 4 March. This date is approximately the same emergence date observed for this population in previous years (McCarley, 1966).

Squirrels remained within 15 to 20 feet of their burrow entrance for two to three days after emergence. Activity was generally restricted to feeding. Walking was usually in a slinking position. Some nest-building was also seen, with grass being gathered within three feet of the burrow entrance. When a squirrel was frightened into its burrow, it remained underground for a longer period than later in the year. Ground squirrels are apparently oriented as to their surrounding upon emergence. Stretching was often seen.

After three to five days, the squirrels move about actively and extend their range of activity up to 50 yards from their nest burrow. Investigation of the area was. 
pursued more intensely. After 10 days, squirrels ranged up to 100 yards from the nest burrow site.

No females were captured before 30 March. However, due to failure to noose some squirrels, this observation may not be valid. The females may have been present but not captured. McCarley (1966) captured females two weeks prior to the first male in one year of his study.

\section{Pre-entrance Behavior}

Just prior to entrance into hibernation in the fall, ground squirrels undergo another marked change in their behavior pattern. Most of the activity consisted of feeding. Some nest-building and evidence of digging was observed. When entrance into hibernation was approximately a week away, the level of squirrel activity decreased sharply. Squirrels usvally fed within 10 feet of the burrow entrances. Often they would sit languidly next to or in the burrow entrance with an apparent lack of vigor. At the slightest provocation, a squirrel would enter its burrow. After entering a burrow, a squirrel was very slow in returning to the surface. Their fur took on a bristly appearance, many hairs standing out at right angles to the body rather than lying flat. 
Juveniles were the last squirrels to enter hibernation. All adults had apparently hibernated by the second week of October. The last squirrel above ground was observed on 22 November. 
CHAPTER IV

\section{DISCUSSION}

Agonistic behavior was observed only 19 times during the nine months of this study, in contrast to 767 encounters observed by Grubitz (1963) in his enclosure populations. Evidence of definite social hierarchies was also found in the enclosed squirrels, but no mention was made as to whether these hierarchies were present at all times of the year or only evident during the courtship period, as was the situation in the cemetery population. This social structure was probably an adaptation to confinement in the enclosure, which reduced active combat among squirrels. In unconfined populations, a temporary social order is apparently established during the period of courtship. This would reduce combat among males and permit more efficient utilization of energy toward reproduction.

"Circling," described by Grubitz (1963), involves two male squirrels both of which assume threat postures, come alongside each other, and engage in a pushing match, pushing with the head and cheek at the hindflanks of the opponent. This may be a show of strength or determination. After an 
encounter, the subordinate stops circling and runs off. No "circling," as described above, was seen in the cemetery, although encounters occurred in which one squirrel made quick thrusts at the hindquarters of another squirrel. Balph and Stokes (1963) suggested that territorial behavior in the Uinta ground squirrel may not be a result of a violation of an area, but an encroachment by another squirrel into the area of a squirrel's individual distance (Hediger, 1950). This is apparently true of the thirteenlined ground squirrel. Burrows are defended, but only by a ground squirrel occupying that particular burrow. Other above-ground agonistic encounters come about as a trespass of the individual distance. The thirteen-lined ground squirrel is not a social animal, and individuals tend to avoid each other. Some instances of agonistic behavior may serve to reinforce the solitary habits of this species.

Observations on shelter-seeking, orientation, maternal, and juvenile behavior were similar to those reported by McCarley (1966). Courtship behavior observed was also similar, except no occasions of "circling" by courting squirrels was seen. "Circling" consists of the male chasing the female in two- to three-foot circles after olfactory investigation. 
The description of locomotion in thirteen-lined ground squirrels corresponds with that of Balph and Stokes (1963) to a great extent. They did not report any tail-flicking as shown by thirteen-lined ground squirrels, where the tail is flicked or waved upon termination of a run.

Different populations of squirrels may exhibit behavioral variation which is ofter subtle or hard to detect. This may result from differences in habitat or population density. An example may be seen in orientation. On the fairways of the golf course, there are not as many points of reference to the burrows as there are in the cemetery. Similarly, the large number of tombstones reduces a squirrel's range of vision and a squirrel could be approached easily by a predator. This may increase the need for a squirrel to be able to reach a burrow quickly. On the golf course, with few obstructions and a long range of visibility, no quick runs for burrows were necessary, and their orientation did not need to be as keen. McCarley (1966) speculated that the density of squirrels in the cemetery was higher than that on the golf course because the obstructions reduced visual interaction between individuals.

Balph and Stokes (1963) stated that the Uinta ground squirrel exhibited stereotyped behavior patterns in many 
instances. This is also true in thirteen-lined ground squirrels. Alert investigative postures, locomotion, and grooming movements, especially stretching, are examples of apparently stereotyped behavior. Orientation, of course, must be learned, and McCarley (1966) following Scott (1958) suggested that young ground squirrels must learn the significance of the distress trills. There are apparent differences in behavior from individual-to-individual, and some of these may be due to learning under slightly different environmental conditions.

The enclosure in which Grubitz (1963) maintained his populations placed squirrels in abnormal situations. Also, he did not maintain a normal seasonal or sexual cycle of the animals in the enclosure. Sexual behavior, including mounting, occurred in February, at least five weeks prior to that in natural populations, and prior to emergence from hibernation of wild squirrels. However, the use of an enclosure to study behavior is justified if natural populations are also extensively studied. Components of behavior, such as postures, sequences, reactions, and the structure of the population can be investigated by manipulation and constant interactions. The investigator must be cautious that behavior is not altered due to the unusual situations encountered 
by the squirrels and falsely interpreted. An ideal study might utilize laboratory, enclosure, and natural situations, observations being conducted concurrently. 
Bailey, B. 1923. Meat-eating propensities of some rodents of Minnesota. J. Mamm. 4:123.

Bailey, V. 1893. The prairie ground squirrels or spermophiles of the Mississippi Valley. U.S. Dept. of Agr., Div. of Ornithol. and Mamm., Bull. No. 4. 69 . p.

Balph, D. M. and D. F. Balph. 1966. Sound communication of Uinta ground squirrels. J. Namr. 47:440-449.

Balph, D. M. and A. W. Stokes. 1963. On the ethology of a population of Uinta ground squirrels. Am. Midl. Nat. 69: 106-126.

Bridgewater, D. D. 1966. Laboratory breeding, growth, development, and behavior of Citellus tridecemlineatus. S. W. Nat. 11:325-337.

Bridgewater, D. D. and D. F. Penny. 1966. Predation by Citellus tridecemlineatus on other vertebrates. J. Mamm. 47:345-346.

Cameron, D. M. 1967. Carnivorous behavior of the goldenmantled ground squirrel. Murrelet 48:13.

Cook, A. H. and W. H. Henry. 1940. Texas rock squirrels catch and eat young wild turkeys. J. Mamm. 21:92.

Desha, P. G. 1966. Observations on the burrow utilization of the thirteen-lined ground squirrel. S. W. Nat. 11: $408-410$.

Edwards, R. I. 1946. Some notes on the life history of the Mexican ground squirrel in Texas. J. Mamm.27:105-115.

Eisenberg, J.F. 1968. Behavior Patterns (in Biology of Peromyscus). The American Society of Mammologists, Special Publ. No. 2:452. 
Evans, F. C. 1951. Notes on a population of the striped ground squirrel (Citelius tridecemlineatus) in an abandoned field in southeastern Michigan. J. Mamm. $32: 437-449$.

Gordon: K. 1943. The natural history and behavior of the western chipmunk and the mantled ground squirrel. Oregon State Mono., Studies in Zool., 5. 104 p.

Green, M. M. 1925. Notes on some mammals of Montmorency County, Michigan. J. Mamm. 6:173-178.

Grubitz, G. 3.963. Unpublished M. S. Thesis. Department of Zoology, The University of Oklahoma.

Hediger, H. 1950. Wild animals in captivity. Butterworth Press, London. $207 \mathrm{p}$.

Howell, A. H. 1938. Revision of the North American ground squirrels, with a classification of the North American Sciuridae. N. Amer. Fauna 56:1-256.

Johnson, G. E. 1929. Hibernation of the thirteen-lined ground squirrel, Citellus tridecemlineatus (Mitchell). II. The general process of waking from hibernation. Am. Nat. 63:171-180.

Kayser, C. 1965. Hibernation (in Physiological Mammalogy). Academic Press, New York, II: 179-296.

King, John A. 1955. Social behavior, social organization, and population dynamics in a black-tailed prairie dog town in the Black Hills of South Dakota. Contr. Lab. Vert. Biol., Univ. Mich., Ann Arbor, No. 67:1-123.

Lyman, C. P. 1959. Blood pressure and other measurements on ground squirrel during the hibernating cycle. Fed. Proc. 18:96.

Linsdale, J. M. 1946. The California ground squirrel. Univ. Calif. Press. $475 \mathrm{p}$.

Marler, P. and W. J. Hamilton. 1966. Mechanisms of animal behavior. John Wiley and Sons, Inc. $771 \mathrm{p}$. 
McCarley, W. H. 1966. Annual cycle, population dyramics, and adaptive behavior of citellus tridecemlineatus. J. Mamm. 47:294-316.

PengelIy, E. T. and K. C. Fisher. 1963. The effect of temperature and photoperiod on the yearly hibernating behavior of captive golden-mantled ground squirrels (Citellus lateralis tescorum). Can. J. Zooj. 41:11031120 .

Rongstad, 0. J. 1965. A life history study of thirteenlined ground squirrels in southern Wisconsin. J. Mamm. 46:76-87.

Scott, J. P. 1958. Animal behavior. Univ. Chicago Press. $281 \mathrm{p}$.

Shaw, W. T. 1945. Seasonal and daily activities of the Columbian ground squirrel at Pullman, Washington. Ecol. 26:74-84.

Wade, 0. 1927. Breeding habits and early life of the thirteen-lined ground squirrel, citellus tridecemlineatus (Mitchell). J. Mamm. 8:269-276.

Wade, 0. 1950. Soil temperatures, weather conditions, and emergence of ground squirrels from hibernation. J. Mamm. 31:158-161.

Zimny, M. I. 1965. Thirteen-Iired ground squirrels born in captivity. J. Mamm. 46:521-522. 